\title{
Comparative Economic Analysis of Rice Processing Methods in Benue State, Nigeria
}

\author{
Tondo, D.T.
}

Department of Agribusiness, Michael Okpara University of Agriculture Umudike, Abia State.

\begin{abstract}
The study examined the comparative economic analysis of rice processing methods in Benue state, Nigeria. Random sampling technique was used to select 63 respondents made up of modern and traditional rice processing methods. The study also identified the major inputs used in rice processing, estimate the cost and returns in processing rice; identify the major factors militating against the modern rice processing methods .primary data were collected using structured questionnaire. The data were analyzed using descriptive statistics, gross margin and cobb-Douglas production model. The result of the analysis showed that the modern rice processors were dominated $(74.6 \%)$ by male while the traditional were dominated (75.4\%) by female. The gross margin for the modern rice processing methods was $N 16,770.00$ per $100 \mathrm{~kg}$ of rice higher than the traditional with $N 4,143.00$ per $100 \mathrm{~kg}$ of rice. The milling capacity of the modern was $200 \mathrm{~kg} / \mathrm{min}$. as against $50 \mathrm{~kg} / \mathrm{min}$. in the traditional methods. The study identified lack of awareness, low capital, poor infrastructure, and lack of skilled technical workers as factors militating on the adoption of the modern methods. The study recommended that the government should subsidized the cost of modern technology equipment's for the processors. The processors should form cooperative groups to help train their members to acquire technical skills and also to access inputs and other resources that will boost their business.
\end{abstract}

Keywords - Comparative, Economic, Analysis, Rice, Processing, Methods.

\section{INTRODUCTION}

Rice supplies 7\% 0f total per capital calorie consumption in Nigeria (1RR1,2015), and occupies about 1.88 million hectares of arable land, making it rank second most important cereal in the world after wheat in terms of processing (CBN,2014). The domestics consumption of rice rose from $5 \mathrm{~kg} /$ person/week in 2012 to about $10 \mathrm{~kg} /$ person/week in 2013 (Okafor and Chima, 2014).Currently, annual per capital consumption of milled rice is $25 \mathrm{~kg} /$ person/month (Musa,2014). The relative ease of its preservation and cooking has influenced the processing trend in its consumption.

The quality of rice has become an important issue among Nigerian consumers who clearly show strong concern for imported rice, because of its quality in terms of cleanliness (WARDA,2015).This has brought about competition of imported rice and locally processed rice. The low quality of locally processed rice reflects low level of improved processing technology. This can reduced the efforts in achieving progress of raising output to meet the consumers demand.

The difficulty of processors in Nigeria to adopt and develop modern technology is due to inadequate resources. Poverty has become a significant factor in increasing processing of rice in Nigeria (Jerry ,2016).One of the major problem of rice processing in Nigeria is to develop appropriate technology. If the cost and returns of processing locally produced rice is known, it will be easy to address the problem of quality in locally processed rice.

Rice processing in Nigeria contributes to food security, employment, poverty reduction and national development. Rice processing is increasingly creating employment for new processors while the old processors have diversified into processing tree crops like cocoa and rubber in which their prices are unpredictable over years now. Income and employment generation in rice processing has been substantial (Msendoo,2016).

\subsection{Objective}

The specific objectives were to:

i. identify major inputs used in processing rice in the study area,

ii. determine the cost and returns in modern and traditional rice processing method,

iii. identify the factors militating against the adoption of the modern method of rice processing in the study area. 


\section{METHODOLOGY}

\subsection{Study Area}

Benue state is located between latitudes $6^{\circ} 11^{\prime}$ and $11^{\circ} 20^{\prime}$

$\mathrm{N}$ and longitudes $5^{\circ} 25^{\prime}$ and $7^{\circ} 15^{\prime} \mathrm{E}$ of equator. It covers an area of $6,250 \mathrm{~km}^{2}$. The mean rainfall ranges between 750 and $1000 \mathrm{~mm}$.The average annual number of rainy days ranges from 190 to 230days. The rains start from April and end in October with the highest point in July. The dry season is from November to March making it conducive for agro-processing. The minimum average temperature is about $27^{\circ} \mathrm{c}$ while the maximum average temperature is $37^{\circ} \mathrm{c}$. The mean relative humidity ranges between $60 \%$ from January to February and $80 \%$ from June to September. The State falls within the guinea savannah vegetation zone. The vegetation supports the production of grains and root crops. The predominant crops are rice, sorghum, millet, yam, maize, groundnut and soya-beans. Benue Agricultural and Rural Development Authority (BNARDA, 2015).This also justified the selection of the study area.

\subsection{Data collection}

For the objective of the study to be achieved, data was collected through primary and secondary sources. This was done through structured questionnaires and internet. The data was collected based on the intensity of the rice processors in the study area.

\subsection{Sampling techniques}

Benue state is divided into three agro-processing zones (A, B and C) consisting of 7 (Ukum, Logo, Kwande, KatsinaAla, Vande-ikya, Ushongu, Konshisha) Local Government Areas in zone A, and 6 (Makurdi, Gboko, Guma, Gwer, Gwer-west, Buruku) local Government Areas in zone B while zone $\mathrm{C}$ has 7(Otukpo, Ohimini, Adhoc, Okpokwo, Ogbadigbo, Oju, Obi) local Government Areas. In each of the zone, 3 local Government Areas were purposively selected based on their intensity in rice processing, making a total of 9 Local Government Areas,7(2 modern and 5 traditional) rice processors were randomly selected making a total of 63 rice processors in the study area.

\subsection{Data Analysis}

Data collected for this study were analyzed using simple descriptive statistics such as frequency tables, percentages and average. Cost and returns of the processors were also determined. Cobb-Douglas production function models was used to determine the efficient use of resources by the processors. The choice of the model was based on a similar study previously conducted by Aondofanan (2016). The ordinary least square (OLS) was used for estimating the parameters in line with different independent variables.

The model is specified as follow.

$$
\mathrm{Y}=\mathrm{a} \cdot \mathrm{X}_{1}{ }^{\mathrm{c} 1}, \mathrm{X}_{2}{ }^{\mathrm{c} 2}, \mathrm{X}_{3}{ }^{\mathrm{c} 3}, \mathrm{X}_{4}{ }^{\mathrm{c} 4}, \mathrm{~d}^{\mathrm{c} 5}
$$

Where: $Y=$ output from capacity of processed rice

$$
\begin{aligned}
& a=\text { constant } \\
& X_{1}=\text { cost of paddy rice } / 100 \mathrm{~kg} \text { of processing } \\
& X_{2}=\text { cost of firewood } / 100 \mathrm{~kg} \text { of processing } \\
& X_{3}=\text { cost of labour } / 100 \mathrm{~kg} \text { of processing } \\
& X_{4}=\text { cost of water used } / 100 \mathrm{~kg} \text { of processing } \\
& C=\text { capacity }(100 \mathrm{~kg} \mathrm{bag}) \\
& D=\text { dummy }
\end{aligned}
$$

Gross margin (GM) analysis was used to determine the difference between the total revenue and total variable cost for the processors.

$\mathrm{GM}=\mathrm{TR}-\mathrm{TVC}$

Where: GM=Gross margin

$\mathrm{TR}=$ total revenue

$\mathrm{TVC}=$ Total variable cost

The Net income (NI) or profit is the difference between the gross margin and total fixed cost of the rice processors.

$\mathrm{NI}$

$=\mathrm{GM}-\mathrm{TFC}$

... (3)

Where: $\mathrm{NI}=$ Net income

$\mathrm{TFC}=$ Total fixed cost

$$
\pi=\mathrm{TC}-\mathrm{TR}
$$

Where: $\pi=$ profit

$$
\mathrm{TC}=\text { Total cost }
$$

$\mathrm{TR}=$ Total revenue

\section{RESULTS}

3.1 The major inputs used in processing rice outside the processing equipments are, Paddy rice, slab for drying, firewood, water, labour, transportation, drums, rakes and sieves.

Table1, shows the estimates of regression in the modern rice processing methods, the result of Cobb-Douglas production function was fitted to find out the relationship between the output of paddy and the independent variables, as supported in a similar study previously conducted by Msendoo (2015). Firewood, labour and paddy rice were significant at $1 \%$ and 5\% respectively. Jerry (2016) in his study confirmed that the cost of paddy rice dominated the processing cost with the processors spending more on paddy. The quantity and quality of rice may have effect on the cost and returns. 
The coefficient of the cost of firewood and labour showed that there was $1 \%$ and $5 \%$ increase in expenditure from its mean level to have a negative effect on output or revenue, while the cost of milling was insignificant. The increase in the cost of firewood and labour will have a negative effect on revenue. However, the cost of water may not affect revenue negatively; but the quantity and quality of water may affect the quality of rice which may in turn affect the revenue. The coefficient of the multiple determinations $\mathrm{R}^{2}$ of the function was 0.568 , which shows that $58.7 \%$ of the variation in output was explained in the independent variables included in the model.

Table.1: Estimates of Regression of Modern Rice Processors

\begin{tabular}{lcccc} 
Variables & Symbols & Regression Coefficient & Standard error & T-value \\
\hline intercept & $\mathrm{A}$ & 10.54 & 29.40 & 0.458 \\
Qty of paddy kg & $\mathrm{X}_{1}$ & $4 \cdot 30$ & $0 \cdot 64$ & $8 \cdot 245$ \\
Cost of firewood & $\mathrm{X}_{2}$ & $5 \cdot 60^{*}$ & $0 \cdot 354$ & $-2 \cdot 895^{*}$ \\
Cost of water & $\mathrm{X}_{3}$ & $6 \cdot 70$ & $0 \cdot 425$ & $-1 \cdot 683$ \\
Cost of labour & $\mathrm{X}_{4}$ & $9 \cdot 404 * *$ & 0.498 & $2.905^{* *}$ \\
Cost of milling & $\mathrm{X}_{5}$ & 7.50 & 0.456 & -1.954 \\
\hline
\end{tabular}

\section{*Significant at $5 \%$, **Significant at $1 \%$}

Table 2 shows regression estimates for the traditional rice processing method. The firewood used in the traditional rice processing system was significant at $10 \%$, while water, labour and milling were insignificant. The coefficient indicated increase in the cost of firewood by $1 \%$ indicating $25 \%$ decrease in revenue without equal increase in the quantity of paddy from its mean. Water, labour and milling cost were insignificant indicating that water, milling and labour had no significant influence on output or revenue in the study. The cost of water was negligible because most of the processors had their own sources of water supply. It was the quality of water used that affect the quality of rice which in turn affects the revenue.

The coefficient of multiple determination $\mathrm{R}^{2}$ of the function was 0.600 , indicating $60 \%$ of the variation in revenue or output as explained in the three independent variables included in the model.

Table.2: Regression Estimates of Traditional Rice Processing System

\begin{tabular}{lccccc} 
Variables & Symbols & Regression coefficient & Standard error & T-value \\
\hline Intercept & $\mathrm{A}$ & $20 \cdot 89$ & $40 \cdot 08$ & 0.534 & \\
\hline Qty of paddy kg & $\mathrm{X}_{1}$ & & 0.0037 & 0.008 & $2 \cdot 284$ \\
Cost of firewood & $\mathrm{X}_{2}$ & $-0 \cdot 350^{*}$ & 0.038 & $-1 \cdot 834^{*}$ \\
Cost of water & \multicolumn{2}{c}{$\mathrm{X}_{3}$} & 0.308 & 0.041 & 1.594 \\
Cost of labour & $\mathrm{X}_{4}$ & 0.218 & 0.018 & 1.684 \\
Cost of milling & $\mathrm{X}_{5}$ & 0.421 & 0.043 & 1.754 \\
\hline
\end{tabular}

\section{Significant at $\mathbf{1 0 \%}$}

Gross margins can be used to evaluate various rice processing situations by comparing different processing methods, estimating profit and loss, calculating costs in processing rice and assist in making investment decisions (Jerry 2016). The gross margin from the modern rice processing method in the study area was $\$ 16,770$ higher than the traditional rice processing method by $\$ 4,143$ per
$100 \mathrm{~kg}$. This may be as a result of adopting the modern technology in processing rice. Despite the fact that the modern rice processing activities add cost to processors, the products could be sold at a fixed price. The result shows that the modern rice processing method is more profitable than the traditional rice processing method. 
Table.3: Gross Margins per $100 \mathrm{Kg}$ of Rice in Modern and Traditional Method

$\begin{array}{lll}\text { Imput } \quad \text { Modern rice processing method( } ¥) & \begin{array}{l}\text { Traditional } \\ \operatorname{method}(\mathbb{N})\end{array} & \text { rice processing }\end{array}$

\begin{tabular}{lcc} 
Paddy rice & 10,000 & 10,000 \\
Fire wood & 1,000 & 400 \\
Labour & 1,000 & 257 \\
Water & 500 & 100 \\
Transportation & 530 & 100 \\
Packing & 200 & - \\
Total-variable cost(TVC) & 13,230 & 10,857 \\
Fix cost(FC) & 500 & 150 \\
Revenue & 30,000 & 15,000 \\
Quantity kglmin. milled & $200 \mathrm{~kg}$ & $50 \mathrm{~kg}$ \\
& $200 \mathrm{~kg}$ & $50 \mathrm{~kg}$ \\
Output kglmin. & 30,000 & 15,000 \\
Selling price /100kg & 30,000 & 15,000 \\
Total revenue (TR) & 16,770 & 4,143 \\
Gross margin $(\mathbf{G M})$ & & \\
\hline
\end{tabular}

\section{Source: Field survey 2016}

The result in table 4 shows that the modern rice processing method milled more $(200 \mathrm{~kg})$ quantity of rice at a time compare to the traditional method that milled only $50 \mathrm{~kg}$ at a time. This is in agreement with Usman (2015) and Yusufu (2014). The benefits of the modern rice processing method include higher $(200 \mathrm{~kg})$ quantity of paddy milled at a time with modern performance operations such as cleaning with water before soaking, parboiling, drying, milling, destoning, grading and packaging. These operations are not practiced in the traditional system thus resulting in broken grains thereby reducing its quality and value.

The modern method soaked paddy for only 6 hours because of its use of hot water while the traditional method takes 24 hours resulting to fermentation of grains giving it an odour after milling. The milling time is shorter (30mins.) in the modern method giving it a high turnover and improved quality as compared to the traditional method.

Table.4: Summary Data on Operations of the Modern and Traditional Rice Processing Method

\begin{tabular}{lcc}
\hline Parameters & Modern system & Traditional system \\
\hline Maximum capacity(kg) & 200 & 50 \\
Number of kglday (6 working hrs=1 day) & 1,200 & 300 \\
Cleaning operation time (minutes) & 50 & - \\
Soaking time (hours) & 6 & 24 \\
Steaming time (minutes) & 40 & 60 \\
Drying time (hours) & 4 & 6 \\
Milling time (minutes) & 30 & 35 \\
De-stoning (minutes) & 20 & - \\
Grading (minutes) & 5 & - \\
Packaging (minutes) & 5 & - \\
\hline
\end{tabular}

Source: (NARPEN) 
Descriptive statistics such as frequency tables and percentages were used to analyze the socio-economic characteristics of rice processors in the study area.

Table 5 shows that the male constitute majority (76.6\%) in the modern rice processing method while the female constituted $75.4 \%$ to form the majority in the traditional rice processing method. The reason could be that the technology involved in the modern rice processing method requires training to handle, maintain and operate them for effective performance. The men could accept the responsibility as an occupation but the female may not because of their position in the family as mothers and would not want to waste time in training before handling the equipment's.

The female had the highest $(75.4 \%)$ over the male $(24.6 \%)$ in the traditional rice processing method because the traditional rice processing method is not complex and does not require special training to operate. This gives the female the advantage to dominate it. Tondo and Iheanacho (2015) confirmed in their study that male were more than the female in the modern rice processing enterprise while the female were more than the male in the traditional rice processing enterprise.

Majority of the respondent $(60 \%)$ falls within the age range of 21-40 years. In the modern rice processing method, while $45 \%$ were between 41 and above years constituting majority in the traditional rice processing method. This means that the modern enterprise is dominated by the younger generations who are more active and stronger. This can be attributed to the fact that rice processing in the study area is tedious and laborious. The success or failure of rice processing depends largely upon how labour and other associated resources are efficiently utilized. Akombo(2015) confirmed in his study that young people within the age bracket of 20-40 years dominated the modern groundnut processing enterprise.

The table also shows that $30 \%$ of the respondents in the traditional rice processing method had no formal education while $40 \%$ of the modern rice processing had tertiary education with others having various level of educational attainment. This implies that majority of the respondents in the modern rice processing method are literate.

The table revealed that $30 \%$ of the modern rice processing spends between 11-20 years processing rice while $30 \%$ of the traditional rice processors had between $21-30 \%$ years of experience in rice processing. This implies that rice processing seems to be a profitable business in the study area, since there is a general believe that nobody will spend several years in an unprofitable business.

The table also shows that $45 \%$ of the processors in the modern rice method had between 1-5 household size while $45 \%$ of processors in the traditional rice processing method had between 10 and above household size. This indicated that the traditional rice processors use members of their household to increase labour that is unpaid, to maximize profit.

Table.5: Distribution of Respondents According to Socio-economic Characteristics.

Modern rice processing method

Traditional rice processing method

\begin{tabular}{|c|c|c|c|c|c|}
\hline Variables & entage & frequency & variables & percentage & frequency \\
\hline Sex & $(\%)$ & & & $(\%)$ & \\
\hline Male & 74.6 & 75 & male & 24.6 & 16 \\
\hline Female & 25.4 & 16 & female & 75.4 & 76 \\
\hline Total & 100 & 90 & total & 100 & 92 \\
\hline \multicolumn{6}{|l|}{ Age (years) } \\
\hline $50-20$ & 25 & 30 & & 30 & 27 \\
\hline $21-20$ & 60 & 50 & & 35 & 33 \\
\hline 41 and above & 15 & 15 & & 45 & 34 \\
\hline Total & 100 & 95 & & 100 & 94 \\
\hline \multicolumn{6}{|l|}{ Education } \\
\hline No formal education & n 5 & 12 & & 30 & 35 \\
\hline Primary education & 20 & 15 & & 25 & 23 \\
\hline Secondary school & 35 & 25 & & 25 & 23 \\
\hline Tertiary education & 40 & 40 & & 20 & 11 \\
\hline Total & 100 & 92 & & 100 & 92 \\
\hline \multicolumn{6}{|l|}{ Experience (years) } \\
\hline $1-10$ & 21 & 20 & & 27 & 23 \\
\hline
\end{tabular}




\begin{tabular}{lcccc}
\hline $11-20$ & 30 & 25 & 22 & 25 \\
$21-30$ & 27 & 23 & 30 & 21 \\
31 above & 22 & 22 & 21 & 20 \\
Total & 100 & 90 & 100 & 89
\end{tabular}

\begin{tabular}{llccc} 
House hold size & & & & \\
\hline $1-5$ & 45 & 40 & 45 & 27 \\
$6-10$ & 40 & 30 & 45 & 30 \\
10 above & 15 & 27 & 100 & 97 \\
Total & 100 & 97 &
\end{tabular}

Source: Field survey 2016

Table 6 shows the factors militating against the adoption of modern rice processing method in the study area, indicating that $19.06 \%$ of the rice processors lack awareness of the modern method of processing rice. The same (19.06\%) of processors suffered from low capital. Poor infrastructure and high cost of equipment were among the factors militating against the adoption of the modern method of processing rice constituting $17.04 \%$. Processors that lack loan facilities to support their business constituted $16.08 \%$, while $14.26 \%$ of processors lacked technical skills in handling the modern rice processing equipment's.

Table.6: Major Factors Militating the Adoption of Modern Rice Processing Methods.

\begin{tabular}{lcc}
\hline \multicolumn{1}{c}{ Factors } & Frequency & percentage \\
\hline Lack of loan facilities & 14 & 16.08 \\
Poor infrastructure & 15 & 17.11 \\
Lack of awareness & 16 & 19.06 \\
High cost of equipment & 15 & 17.04 \\
Lack of technical skill & 12 & 14.26 \\
Low capital & 16 & 19.06 \\
Total & 88 & 100 \\
\hline
\end{tabular}

Source: Field survey 2016

\section{CONCLUSION}

In conclusion, the study revealed that the modern and traditional rice processing methods were practiced in the study area. However, the traditional method was commonly practiced with few modern methods. The few modern rice processing methods had higher $(200 \mathrm{~kg} \backslash \mathrm{min}$.) capacity of milling rice than the traditional $(50 \mathrm{~kg} \backslash \mathrm{min}$.) method and is more efficient though underutilized due to inadequate supply of paddy rice.

The study also revealed that the cost of paddy rice dominated the processing cost which means that, the processors spend more on purchasing paddy rice. Although the cost of water did not negatively affect revenue but the poor quality and quantity of the water may affect the quality of rice which in turn affect the revenue.

There was increase in the cost of firewood by $1 \%$ indicating $20 \%$ decrease in revenue. The cost of water, labour and milling was insignificant indicating that water, labour and milling had no influence on output and revenue.
However, the quality and quantity of water affected the quality and revenue of the rice.

The gross margin for the modern rice processing method was $\$ 16,770$ per $100 \mathrm{~kg}$ of rice higher than the traditional ( $\$ 4,143$ per $100 \mathrm{~kg}$ ) method. This shows a clear result of adopting the modern rice processing method. The modern rice processing method had a higher $(200 \mathrm{~kg} \backslash \mathrm{min}$.) capacity of milling rice than the traditional with the capacity of milling $50 \mathrm{~kg} \backslash \mathrm{min}$. of rice. The modern rice method soak paddy in a mechanically hot water tank for 6 hours and dry for 40 minutes before milling. While the traditional method manually soak paddy in cold water for 24 hours resulting in fermentation of the paddy giving it an odour after milling which lead to reduction in quality and revenue.

Majority (74.6\%) of the modern rice processors were male while $75.4 \%$ of female were in the traditional method, indicating that male were more in the modern method of processing rice while the female were more in the traditional method. The modern rice processors constituting 
$60 \%$ were within the age range of 21-40 years while $45 \%$ of the traditional were 41 and above years. This shows that young rice processors were more in the modern rice processing method than the traditional method.

A higher $(30 \%)$ of traditional rice processors had no formal education while $40 \%$ of the modern rice processors had tertiary and various levels of educational attainment. This is an indication that the modern rice processors were more literate and could plan better on how to utilize their human, materials and financial resources for better output and revenue.

The modern rice processors who had 11-20 years of experience in processing rice constituted $30 \%$ while $30 \%$ of the traditional had 21-30 years of experience in processing rice. This shows that rice processors with high years of experience were more in the traditional than the modern method, indicating that the traditional existed long before the modern.

The modern rice processors who constituted $45 \%$ had household size of $1-5$ persons while $45 \%$ of the traditional rice processors had household size of 10 and above persons. This result is an indication that the traditional rice processors were using their household size to complement their labour force that is not paid in other to maximized profit.

The study also identify factors that are militating against the adoption of the modern rice processing method to include lack of awareness and low capital to constitute $19.06 \%$, poor infrastructures and high cost of equipment to have $17.04 \%$ while the rice processors who lacked technical skills constituted $14.26 \%$.

\subsection{Recommendation}

Rice processing is discovered to be a profitable business that can create employment to reduce the rate of unemployment in Nigeria. It also provide revenue through tax to the government, generate income for the owner, contribute in addressing the social needs of the society and above all, address the problem of food insecurity in Nigeria. Based on the above, there is need for the government to encourage rice processing business, most especially the modern method in Nigeria. This could be achieved by providing counterpart funds to financial institutions to loan to rice processors who have seen the need to adopt the modern method of processing rice for higher capacity. This may contribute in addressing the shortage of locally processed rice in Nigeria.

The government should also provide basic infrastructures such as storage houses, good rural roads to help reduce cost on the side of the processors. Government should also help to subsidize the cost of modern equipment to enable processors replace their spoiled parts to put back their equipment's to work.

The processors should form cooperative groups to help train their members to acquire technical skills that will help them handle their equipment efficiently and effectively. The cooperative groups will also help their members to access inputs and other resources that will help to boost their business.

\section{REFERENCES}

[1] BNARDA. (2015). Annual Report on Climate Change in Benue State From 2010-2014. Benue Agricultural and Rural Development Authority. Makurdi.

[2] CBN (2014). Annual Report on Rice Production, Processing and Marketing. Central Bank of Nigeria. Makurdi

[3] IRRI. (2015). Rice Almanac. International Rice Research Institute Los Banos.

[4] Jerry, A.T (2016). Profitability of Rice Processing Among Youths in Benue State, Nigeria. A Paper Presented in Vande-Ikya Youths Rice Cooperative Society. 14 ${ }^{\text {th }}$ April, 2016.

[5] Msendoo,N.T. (2016). Adoption and Impacts of Improved Rice Processing Technology: A Case Study of the Cameroon Grains Development Project. Economics Working Paper (80-100).

[6] Musa, D.A (2014).Comparative Economic Analysis of Improved Rice Processing Technology and the Traditional Technology in Selected Local Governments Areas of Taraba State, Nigeria. A conference paper presented at Taraba State University, Jalingo $.17^{\text {th }}$ May, 2015.

[7] Okafor, C.A, Chima,K.J. (2014). Economic Analysis of Local Rice Processing in Selected Local Government Areas in Kwara State, Nigeria. A conference paper presented at Benue State University, Makuridi.19 ${ }^{\text {th }}$ July, 2015.

[8] WARDA. (2015). Essence of WARDA, The Reason Why Nigerians Are Hooked To Rice Importation. Insights from a Comprehensive Rice Sector Study. The African Rice Center 2:1-4. 